\title{
Addooyyee: Girl's Indigenous Friendship Institution in Oromoo, Ethiopia
}

\author{
Megersa Regassa *; Terefe Mitiku; Waktole Hailu \\ Department of Oromo folklore and Literature, Jimma University, Ethiopia \\ Email:waktoleh@yahoo.com
}

http://dx.doi.org/10.18415/ijmmu.v6i1.620

\begin{abstract}
This thesis explores the role of the addooyyee institution in making friendship and sisterhood relation among girls. It aims at discussing the procedure by which addooyyee established between girls and used as girls' friendship. During data collection, ethnographic methods such as observation, focus group discussions and semi-structured interview were employed. In data analysis, interpretive method was used to discuss the collected data. The analyzed data shows that, the addooyyee institution has vital role in making friendship and sisterhood relation among girls in their social, economic and cultural life. The institution strengthen the relation of girls during wedding ceremony, working hand crafts (hodhaa), and their journey to collect firewood and migira buqqisuu (uproot grass), decoration wisdoms and daboo dubartii (girls' cooperative work). Girls run all the above systems through their addooyyee institution to help each other and to exercise their friendship and unity among the society as gender based traditional institution. The thesis concludes that the addooyyee institution enables girls to come together and help each other in their social, economic and cultural life. To windup, concerning bodies should have to use this readymade institution in helping girls to strength their relation in all aspects of social activities.
\end{abstract}

Keywords: Addooyyee; Girls’ Institution; Friendship; Maccaa; Oromoo

\section{Introduction}

Women have been considered as vulnerable members of society throughout history. Their vulnerability is because they are physically not strong as men. Therefore, they considered to need extraordinary customary legal protection (Beck, 2001 and Lansdown, 1995). Gemechu (1993 stated in Kuwee, 1997) reported that women were considered vulnerable part of the society and regarded as muka laaftuu (soft wood). Therefore, the law of muka laaftuu protects their right. The law is in the siiqqee institution that protects the right of women by functioning hand in hand with Gadaa system.

Some African society has customary law to protect women's human rights (Abass, 2010). For instance, among Kom of Cameroun, Gikuyu of Kenya, and Igbo of Nigeria, there is traditional decentralized democratic political system with a grassroots-based leadership, and women had their own self-government in the political system. In these societies, women have economic power, strong social organization, and a deep sense of female solidarity (Amadiume, 1997). Baines, (2012) argued that 
implementing customary law and institutions in constitutional rights encourages the protection of women's rights by bottom-up rather than top-down approach. The bottom-up approach is more likely to have the support of the community, with no cost to women. Otherwise, the community's opposition makes it harder, if not impossible, to implement women's rights by any mechanism. Therefore, implementing women's institutions customary law in light of present day condition have vital role in protecting violation of women's right (Abass, 2010).

The discrimination of women became harsher after the decline of the egalitarian social institutions of pre-colonial African societies (Bula, 2008). Therefore, without implementation of women's indigenous institution and laws, protection of rights of women cannot be realized (Baines, 2012). For instance, in Arsi Oromo, after the decline of Gadaa system to the clan level and the separation of the family and the land from the communal ownership, women being undermined in the family, became socially and economically dependent. This brought out in the detention of women to a single family and removed their earlier decision making power which has resulted in their relegation (Daniel, 2002). Additionally, with the decline of Oromo traditional institutions, socio-economic status and political roles of Oromo women declined swiftly and presently they are leading destitute ways of living. The problems have been largely credited to the far-reaching colonial conquests (Emperor Menelik's Empire in the late 19th century), religious expansions (introduction of alien religions such as Islam and Christianity), appearance of statehood and economic crisis (Bula, 2008).

Therefore, there is a need for women's rights scholars and activists to seriously consider human rights discourses that engage with customary law as one of the possible solutions to women's rights violations. Customary law can be used to advance women's rights through custom, tradition and culture that valued women and their role in society (Baines, 2012). Among the Oromo, there are different cultural institutions and ceremonies which are concerned with status of women among the community in their social life. The institutions also help women to fight for their right and strength their unity and friendship. For instance, Daniel (2002) and Jeylan (2004) showed that Ateetee, qanafaa and siinqee institutions are indigenous institution of Oromo women by which they defend the violation of their right. Furthermore, (Østebø 2009) also discussed that when women's right is violated, religious marches as well as political mobilizations conducted through Ateetee and siinqee institutions.

Addooyyee is the women friendship institution by which they help each other during their wedding and other special cultural occasions (gubirmans.com, Oromiatimes.blogspot.com, Tsega 2012). These articles and book, roughly discussed the role of the Addooyyee institution in peace making. The previous studies focus on women rather than girls. To fill the gap, this study focused girls' institution.

\section{Materials and Methods}

During data collection for this research, qualitative methods were employed. By qualitative data gathering methods, the qualitative data will be gathered from the field. The collected data will be interpreted and analyzed qualitatively in the descriptive and expressive manner. Therefore, the qualitative data collection methods such as observation, interview and focus group discussion were employed during this research.

\subsection{Methods of Data Collection 2.1.1 Observation}

The ways in which girls help each other were observed by researchers in the study area. The researchers observed gifts that were given for the bride from her Addooyyee institution during her 
marriage ceremony. Additionally, Addooyyee rituals on which girls establish their friendship were observed. Before we went to the field, we consulted girls and identified the time and the place at which the ritual could be practiced.

\subsubsection{Interview}

In this research, three interview techniques were used. One is informal interview. By informal interview, the key informants were selected and important general information about the issue was gathered. In this case, informants were selected informally on the road, at work place, at market, in the town and other social gatherings. Additionally, in-depth interview were employed. The key informants were selected from the community and the interviews were conducted until the data get in touch with the saturation point.

The last interview technique that was employed during data collection for this research is semistructured interview. By this method, data were collected from key informants. Key informants were selected from the community depending on their deep knowledge about culture in general and Addooyyee institution in particular. Our key informants were from women elders, girls and married men who married woman practiced the ritual and have experience about the issue. The guiding questions were prepared to help the interviewee to discuss about issue of the study as much as possible. Generally, twenty-five (25) key informants were selected and interviewed depending on the time given and sufficiency of the information.

\subsubsection{Focus Group Discussion (FGD)}

In this method we gathered informants from the similar background and experience. We formed four FGDs, at East Wollega Zone (two FGDs at each two districts, Gidda Ayyaanaa and Limmuu). Two FGD had eight informants and other two had ten informants. The experienced women informants were selected purposely from the community. In each district, the three groups consist of girls and one group was married women. The districts in which the focus group discussion conducted were selected purposely. During the discussion, we facilitated the discussion by preparing key questions, discussion issue and encouraging all informants to participate in the group. FGD helped us to cross check information that were gathered by observation and interview techniques. Additionally, we recorded their sound by tape recorder. We took field note by listening at the discussion.

\subsubsection{Sampling Techniques}

In this research two types of sampling techniques such as purposive and snowball sampling was employed. In case of using purposive sampling, for objective of this research, the girls and women who practiced Addooyyee ceremony were judgmentally selected. Researchers purposely selected these women and discuss with them about the issue. The Researchers used snowball sampling to get experienced women from the community and information was collected from them. After that, they were requested to tell researchers other experienced women from the community and people selected by them become part of the sample. Then, information was collected from them and those people were asked to identify other members of the group and in turn, those identified become informants. This process was continued until saturation point reached.

\subsubsection{Data Management}

We have analyzed the data collected from the field qualitatively. In the analysis, first we have transcribed the raw data collected from the field. After transcription, we arranged them in the logical order in terms of their theme, patterns and structure. In ordering, we have designed skeleton structural 
titles for the data and then discuss it in the very meaningful way. After the data ordered in meaningful way, we have written the paper.

\subsubsection{Maccaa Oromo: An Overview}

The Oromo whose origin is rooted in one source had in the course of historical periods multiplied itself into various branches that collectively evolved to its present stage of a nation. As Gemetchu (1993 stated in Dejene 2007), the Oromo divided into five major groups: the Tulamaa and the Macha, the Sabboo and the Goonaa, the Rayyaa and the Aseboo, the Siikkoo and the Mando and the Ituu and the Humbannaa.The Borana section of Oromo divided in to three confederacies, namely Tulama-Matcha (northern Borana), the south Borana and Gujji. They had common Chaffe at in Fatagar at a place called Oda Nabi (Mohamud 1994). Alemayehu (2006) also argued that among the main branches it formed in that historical period, one is known as Macha. Their founding father was Rayya. Rayya has four branches. These are known as Macha, Tulama, Wallo and Karrayyu. When we count the genealogy of the Macha from the beginning it is addressed as: Horro Oromo Borana G`urracha Nagewo Oda Walabu Rayya Macha. Macha has branches such as Amuru, Horro, Jimma, Limmu, Ibbantu, Liban and Jidda.

According to Alemayehu et al (2006), the term Macha means very wide and large number of population. The present day settlement areas of the Macha include Western Shawa, Southwestern Shawa, Jimma, Ilu Abba Bor, Eastern Wallaga, Western Wallaga, Wambara and Gojjam administrative Zones. Mohamud (1994) discussed about separation of Matcha and Tulama. As he, addressed Matcha and Tulama had common Chaffe assembly at Oda Nabe in Fatagar. Later on Hoko, Tchalliya, Guduru, and Liban where detached from Tulama and moved to western direction. Alemayehu et al further explain that the separation of Macha and Tulama that while separation Macha made a short stay at Qoricha and then moved to place called Oda Bisil a specific place named Tute Bisil. Mohammed 1994 added that the four Matcha classes were called Afre confederacy (confederacy of four) which were formed during Robale Gadaa (1570-1578). During the period of Birmaji Gadaa (1578-1586), as the author portrayed, second Matcha confederacy, the sadacha (confederacy of three) was formed. These were composed of Obbo, Suba, and Hakako. These groups moved to southwestern region. Mohammed discussed that, distance between them and the central chafe, Oda Nabi extended and it was become difficult to go there. As a result, Matcha founded new center called Oda Bisil (or Tute Bisil) which located between Gedo, Billo and Gibe rivers.

Mohammed (1994) thrashed out the movement of Sadacha branch of the Matcha towards west and southwest namely Gibe region of which Ennarya formed the dominant part. Afre branch directed their movement towards the west and southwest, administrative region of Wallagga and Illubabor. Tesema Ta'a (2006) also discussed that the Macca consequently split into a number of clans and sub-clans including Leqa, Sibu, Tume, Amuru, Guduru, Nono, Jimma, Wallaga, and Hulle. These groups also dominantly inhabit in whole region between the Abbayya in the north, the Dabbus River and Tullu Walal in the west, and Gojab River in the south.

\section{Results}

\subsection{Concept of Addooyyee Institution}

Addooyyee institution has social, normative and regulative structure that persisted by laws, rules, beliefs and behavioral roles of the Oromo. It especially derived from gadaa system in which its principles focuses on gender equality which addooyyee institution is one version of gadaa in relation to equality. Addooyyee is the sisterhood or friendship institution established by girls of the same mate during their adolescence age. It is promise made between two and more girls to be close friend, to repute each other, to help each other, to love each other and not to call each other by their respective name; instead, to call each other addooyyee. Adooyyee sometimes called hiriyyee or saakumee (close friend); however, 
addooyyee is prevalent and formal term used to embody the concept. After the establishment of the addooyyee between girls, they do not call each other by their name; they call each other addooyyee throughout their life. The friendship established between girls through addooyyummaa (addooyyee'ness or friendship) is not short time friendship, it is lifelong friendship.

\subsection{Establishment of Addooyyee Institution}

During establishing addooyyee institution, girls come together and take a promise of addooyyummaa. The addooyyee can be established between girls who have blood relation and also those who do not. The promise has cultural procedure and practice. They practice it at the river when they fetch water or collect firewood. After deciding to be addooyyee for each other, they come to the river where the callaadduu (tall grass which grows at riverbank) grows and uproot it. By holding the callaadduu they take the promise oath. Callaadduu is green and beautiful and it symbolizes happiness and harmony relation of girls in their life.

During the promise or oath, they hold the calladduu they uprooted separately and bring it together. Holding the callaadduu they say:

Walii kakanna, kakuu addooyyee

Kan hin banne hin cabne

akka calladduu kanaa

Waaqni Waliin nu haa bareechu Jaalalli keenya haa jiidhu, haa lalisu

Aannaniifi garaa nu haa godhu

Nuti ammaa booda addooyyeedha

Addooyyee jennee wal waamna

Maqaa dhalootaa wal hin waamnu

Nuti waliif saakuma, horiiyyadha

Saakumaa, foon keenya tokko

Dhiigni keenya tokko

$\mathrm{Nu}$ waliif addooyyeedha

Walitti hidhamneerra

Walitti makamneerra

Addooyyeen wal waamnaa

Yeroo rakkinaas yeroo ballinaas

Wilbira dhaabanna, walhirkifna

Hirkoo walii taanaa

Wal bira nu haa bushu

Wal biratti nu haa tiksu
Let us take oath, oath of friendship

The oath is forever

like the callaadduu

God make us beauty

May our love grow

May God strength our love

From this time, we are adooyyee

We call each other addooyyee

We never call each other by our name

We are friend

We are relative

We have blood relation

We are addooyyee

We are tied together

We are mixed together

We call each other addooyyee

Both during terrible and happiness

We support each other

We help each other

My God give us lifelong together

May God keeps us peacefully

The above oath taking ritual is practiced between girls who decided to be addooyyee for each other. Before the oath, they discuss about the importance of having addooyyee and the service they offer each other after the establishment. As the above oath statement shows the addooyyee have great role for keeping solidarity between girls, even after their marriage. The statement shows kakuu addooyyee (addooyyee's oath) is unbreakable and unforgettable. They also say foon keenya tokko, dhiigni keenya tokko, walitti makamneerra that means 'our flesh is one, our blood is one, and we are mixed together.'

This shows that even though they are two or more people, they are united and they consider themselves, as they are one person. This is how they show that their love and friendship as addooyyee is profound. When they say, our flesh and blood is one, they promise that as one like and think for his/her 
life, addooyyee also have to think for her respective addooyyee. So that, they visit each other during hardships like ill, death and others. More will be addressed in the next topics.

\subsection{Means through Addooyyee Institution in Strengthens Girls' Friendship 3.3.1 Marriage Ceremony}

During their marriage ceremony, addooyyee institution come together and performs song to beautify their marriage ceremony. The song is performed during the jal-bultii marriage ceremony. When one of their addoyyee has marriage ceremony, all of her addooyyee come together and perform song at her family's home for two weeks. This ceremony continues until the wedding day. The song performed have different objective. By the song, the addooyyee of the bride advise her, wishes her good life in the future family, and praise her. Addooyyee of the bride also insults the groom and his relatives, arrabsoo durbaa (girls insult) through cultural songs.

The addooyyee are grow up from their child hood until the time of marriage in one area playing different child games from hawwaara daakuu, (grinding dust), preparing "false bread" from mad, to collecting faggots, fetching water and performing folk songs. Their relationship starts at their childhood. When a girl gets married from the addooyyee institution, the others feel grief. They feel sad because their addooyyee going to be separated from them physically in case of residential place. They express their feeling through oral poetry saying:

Agadaa mataa shaashuree Akkamiin cabsuree Addooyyee marii yaadanii Akkamiin obsuree
Cane, which have flower head

How to harvest it

Missing counselor, addooyyee

How to get condolence

In this above oral poetry, girls condemn the separation of the addooyyee institution and the bride. They say that missing addooyyee amongst them is miserable. It is bad for the addooyyee institution to see their addooyyee separated and departure from them for marriage purpose. Therefore, on the jal-bultii ceremony, the addooyyee of the bride come together and praise the friend (addooyyee), seenaa dhaamu or mararoo (good by song), insult the groom and his relatives. When they insult the groom and his relatives, they get relief from their grief. They also psychologically prepare their addooyyee for the inevitable marriage and their departure. On the day of wedding, addooyyee of the bride, afford her gonfaa, dowry (gift from relatives and friends for the bride on her wedding day). The practice is known as gonfuu (giving gift). On the day of wedding, this gift collected from her addooyyee institution and relatives and distributed to the hamaamotaa (accompanies of the groom) and they take it to the home of the groom. This gonfaa given by addooyyee for the bride are material cultures such as sharfee, gundoo (plate like utensil made from grass), mosobii (plate like material made from grass and used to preserve bread), gilgilii (round container used to serve local bread mixed with stew), and mudaaye. Presently, her addooyyee also buys plate, fork, coffee cup, and other domestic materials from shop and present for her on the wedding day as gonfaa (gift). The addooyyee also make uffata siree (bed wearing) from threads by their craft. This is new trend in the society; because the craft is newly introduced handcraft.

Addooyyee institution of bride's mother also prepares cultural dressings such as balee, gaabii, qoloo and gives it as gonfaa. All these cultural dressings are locally made from cotton. This shows that addooyyee institution gives those gonfaa for the bride so that she uses these materials at her new home. In addition to using it at home, the couple also sells materials and buys livestock by income they get from the gonfaa. This becomes the basic livelihood of the couple to start bearing property.

Some of the gifts also given for relative of the groom like uncle, mother, father, sister and other close relatives. In response, those who received the gift must have to give them a property. They give calf, 
goat, sheep, cow, ox or piece of farmland. These properties enable couple to establish their new life with certain property. In addition to the material benefit of these gifts, having large amount of gonfaa is pride for the bride and her addooyyee institution in the community, especially from the side of the groom. The bride who have not brought large amount of gonfaa is criticized as if she have no addooyyee and relatives. From the side of the groom, when the bride arrives to the house of the groom, girls ask her about the gonfaa through oral poem. They say:

Dhibba shaniin sinaqqannee

Bara shanoo si kadhannee

Meerree gonfaan?

Maali dhoksaan immoo?

We paid five hundred brides wealthy

We waited you for five years

Where is gonfaa, gift?

There is no any secret

Dhibba shaniin si naqannee (we paid five hundred bride wealthy) implies that the groom have paid enough amount of bride wealthy that would use to buy the gonfaa (the gift). Bara shanoo si kadhannee (we waited you for five years) implies that the bride and her addooyyee institution had enough time to prepare the gonfaa for the bride. The girls saying that, since the enough time and budget is allotted for the preparation, why gonfaa (the gift) is not presented or become inadequate. If the gonfaa is enough, the bride feels confident. It said to be 'sirriitti gonfamte' that means 'the gift is enough.' Therefore, the addooyyee institution works hard in preparing hodhaa and buying other materials as the gift to rescue their addooyyee (the bride) from the criticism.

Yaa geeshee minaan mukaa yee

Addooyyeen gadqaaritee

Geggeesseen biraa dhufaa yee

Yaa deesse jabaadhu kaa yee
Oh geeshee tree of grain

Addooyyee is going out

I am saying her well go

Oh mother, take condolence

By the above oral poetry, addooyyee of the bride wish condolence for the bride's mother. Not only her mother, also commiserate themselves by the oral poetry. In the above oral poetry, addooyyee is the bride departing from them for marriage. Adooyyee of the bride offer condolence for her mother by performing the above song. They beat their dibbee (drum) and perform the song. By the song, they say her stay in peace (well go) (nagaa dhaamuu). They reveal the love they have for their addooyyee who is going for marriage. When she hears this song of addooyyee, the mother of the bride mourns. Not only mother, relatives also mourn. They reveal love they have for the bride. Addooyyee of the bride are not happy for their departure because of the marriage. They express their sorrow by the oral poetry.

\subsubsection{Addooyyee Institution in Handcraft (Hodhaa)}

Addooyyee institution makes hodhaa (grass basketry) and give for one another on their marriage ceremony. Hodhaa is the household materials made locally from migira (grass).The hodhaa which addooyyee give for each other are materials such as sharfee, painted sharfee, gundoo, gilgilii, mosobii, mudaaree, shillaawoo and others. Addooyyee made these materials and give it to the bride as a gift during the marriage. Addooyyee institution starts to prepare these materials for the bride, which is member of their institution one year ahead of marriage ceremony. They prepare it and preserve it until the day of marriage. They give gilgilii to faaqii (tanner) to cover hide to it. After it prepared they preserve it to the day of wedding. Girls usually get married one year after promise for marriage. The one-year time gives chance for addooyyee institution to prepare gifts for the bride. On the day of marriage, addooyyee of the bride collect all hodhaa, gift they prepared and give it. 
Girls are praised for making hodhaa, it is their identity. They like to make hodhaa for their addooyyee who is getting ready for marriage and for themselves on the day of their marriage. Girls also sell the hodhaa at the market and it is one source of their income. Usually, one visits a girl with mutaa, shutaa, and migira. The girl shows their sentiment to their hodhaa by oral poetry. They say:

Gundoo marsaa hodhinaa

Ishee qalamii qabduu

Waggaa waggaan sirbinaa

Warri alamii qabnuu
We make round plate

Which beatified by color

We sing year by year

We are those who have good luck

The above song is performed by girls. Girls make gundoo in particular and hodhaa in general. Girls like to make hodhaa. They make hodhaa when they are watching after cows, crops and at home after they finish homestead works. Girls also like to perform songs with their addooyyee institution. This is the most important event that makes them happy in their life. There is no happy life for girls than meeting each other and performing song with their addooyyee institution. After marriage they miss such like life. That is why they poeticize the above oral poetry during the song. They perform the above song during marriage and other ceremonies. They say "gundoo marsaa hodhinaa ishee qalamii qaabduu; waggaa waggaan sirbinaa warri alamii qabnuu" which means "we make round gundoo which is painted and we those who have good luck sing year by year.' Those who have good luck are girls who are not married and living with addooyyee institution. Therefore, those who are unmarried are happy of being with their addooyyee institution and making their hodhaa. There is also the proverb which shows how much girls like their hodhaa. It says; "Yaa migira koo, yaa fira koo' jette intalli butamte." This means, 'the abducted girl cries for her migira and relatives.'

\subsubsection{Addooyyee Institution in Migira Buqqisuu (uprooting migira)}

Girls of addooyyee institution plays with each other, laugh, and enjoy happy life with each other during uprooting migira (grass) used to weave basket. They weave hodhaa (grass basket) by coming together; they learn the technique of weaving hodhaa from each other. Senior girls learn from the juniors by coming together according to their addooyyee institution. When they come together to make hodhaa, they share their experiences and discuss their issue. When spring season comes, girls come together for migira buqqisuu (uproot migira). On the way to where migira grows, they play with each other. That is part of their entertainment time. They discuss many issues about themselves. They share their experiences. The same is true when they come back. At home, they also come to one place and tear the migira. After they tear it, they tie it to bundle and place it on the grass house to make it dry by sun heat. The migira grows in the baddaa, high land areas. They say it migira baddaa, migira of high land. Girls go a long journey to where the migira grows which are highland areas. They arrange the journey according to their addooyyee institution. By the migira, they make different materials and give for the bride who is going for marriage among them as part of dowry. They perform song during uprooting the migira. The girl's song about migira baddaa (highland grass) and uprooting it at the spring season is:

Baddaa baddaa migiraa

Ya callaadduu birraa

Waggaa waggaan sirbinaa

Nuti ayyaantuu jirraa

Migira that found in highland

Which like callaadduu of spring

We sing year by year

We are living in good luck 
The above oral poetry shows that migira (grass used to make basket) grows at baddaa, high land areas. It grows well at the area, it looks like the callaadduu (tall green grass grow at water shore) of spring season. Callaadduu passes trouble time during summer season. The flood mix it to the mud and it is not conducive to grow. At spring, when the flood passes it start to grow well and it make beautiful green area around the water shore. Therefore, the oral poetry of girls compares the migira with such like green calladduu during the spring. Migira also mature for uprooting during the spring season. Therefore, girls perform the song during this season and uproot the migira. They uproot the migira in-group as their addooyyee institution. This is the most interesting life of their time. Nevertheless, the girl who is going for marriage misses such like life. The oral poetry shows that, those who are not married continue to uproot the migira with each other and perform song, enjoy life with each other. Therefore, they are ayyaantuu, fortunate. In contrary to that, those who are married miss the enjoyment.

Uprooting magira make a conducive environment for addooyyee institution to come together and share their experiences. They play and work together. They also uproot by daboo, cooperative work. They help each other in uprooting it according to their addooyyee institution. They also tear it in daboo or daadoo (cooperative work turn by turn). In daadoo they tear for each other turn by turn. When it became dry, they start to weave the material from the migira. They weave in-group according to their addooyyee institution friendship. They decide a center where to come together to weave. It helps them to share their craft of weaving and making new design. It is the place where the junior girls learn the craft from their seniors. Sawing in group also help them to discuss a lot of issues about their life. Since male are not with them, they are free to discuss what they want on the stage.

During uprooting migira and weaving girls, perform the following song as:

Ishoo lolee

Bishaan haa taliiluu

Sirbi hiriyyee

Birraan haa bariituu

Joyful

Let water be clean

Sing friend

Let spring season come

Girls wait hopefully the coming of the spring season. The oral poem tells that during the winter season water or river floods and restricts girls to come together from far places. The winter time is also rainy season so that they are busy of agricultural works. However, during spring season agricultural work is finalized and flood decreases so that girls arrange their journey for uprooting migira where it grows. When girls come together at this season, they perform above oral poem. Ishoololee bishaan haa taliituu sirbi hiriyyee birraan haa bariituu which means 'let water be clean and let spring season come then we perform song.' It implies that hiriyyee are happy to see coming of this spring season so that they enjoy life together.

\subsubsection{Addooyyee Institution in Firewood Collection}

Household jobs in general and collecting firewood in particular considered as responsibility of women and girls. Therefore, addooyyee institution goes to the forest area to collect firewood with each other. Their voyage to the area is in-group according to their addooyyee institution. They collect the firewood in-group and help each other in tying the collected firewood. They split the firewood by helping each other; they load on each other. The boys go to the place where girls collect the fire hood for love. 
The boys collect, split and arrange the firewood for their lovers. They play and make a love dhungoo or qabdoo (kissing) with their respective lovers in the forest where no one could see them.

There is oral poetry poetized by boys for girls to go out from home to collect firewood so that he should get chance to make love with her. It says:

Waaqayyoon maalan godhe? What I sinned Waaqayoo (God)?

Kan bokkaa rooba dhowwee Why he protected rain

Qilleensa gad-kaachisu

Abbaayyee maalan godhee?

Blowing wind

Kan shaggee laga dhowwee

What is wrong between me and your father?

Bineensa na nyaachisu

Why he restrict his daughter from river

Beast eats me out side

Laga qoraanii (forest area far from village) is where girls goes according to their addooyyee institution to collect firewood. At the place they are free to discuss whatever they want and meet their lover. They can discuss about who to love or not to love, about their marriage, their friendship, their addooyyummaa (addooyyeeness) they establish and strength their addooyyee institution. Strengthen their unity. If one boy loves certain girl and hesitates to tell her, he uses her addooyyee as mediator. This is because, addooyyee do not hesitate each other, do not have any secret among each other. They also keep their respective secret strongly. If the lover of the boy obeyed the request, the addooyyee arrange program to join two lovers; one of the place is laga qoraanii (where to collect firewood).

At the place, the lovers discuss a lot of issue; they can initiate the draft the idea of establishing marriage in the future. Boys could not rape girls and could not abduct her against her wish. Raping girl is against norm of the community. At laga qoraanii, since her addooyyee is with her lover or any other man cannot rape or abduct girls. They do not allow conducting such like things against her wish. Therefore, addooyyee institution strengths girls unity and enable them to defend each other from harmful practices such as rape and abduction.

\subsubsection{Addooyyee Institution in Decorating Each Other}

Addooyyee institution decorates gum for each other; they prepare folk medicine to decorate it. They decorate one another's gum by painting charcoal and piercing by needle or thorn. The girls come together according to their addooyyee institution and practice this decoration. Those who have no addooyyee could practice it with others. They decorate each other's gum (foon ilkaanii). The decoration is called ilkaan tumachuu or tumaa. The preferred type of gum decoration is guraamalee. Guraamalee, is decorating gum straight to one teeth and letting aside the other turn by turn. The girl who decorated her teeth does not laugh to red man. Because, it believed that the charcoal would disappear. However, she can laugh with, black person. They advise each other this norm. Addooyyee institution also pierces each other's ear, which is called gurra urachuu (piercing ear). They pierce each other's ears by thorn of acacia tree. Because, wound by thorn of this tree healed in short period. A girl has to prepare bread for her addooyyee who pierced her ear. It believed that, unless she serve her addooyyee with the bread, the wound could not heal in short period. The adooyyee who helped to pierce, eats the bread and spite to the pierce or wound; so that it healed definitely.

Addooyyee institution also makes qarree for each other. Qarree literally refers to girl's traditional hairstyle shaved at top of the head designed in circle. Qarree is the symbol of unmarried girls, it is symbol of virginity. Qarree of younger girls is small and that of matured girls is more large or wide. They made it by razor. Addooyyee institution come together and shaves it for one another. They meet each other for this purpose, but they can discuss about their unity at the stage. Therefore, this qarree haaduu (shaving qarree) practice also strengthens the friendship among girls.

3.3.6. Addooyyee Institution as Self-help Organization 
Addooyyee institution has self-help organization through which they help each other during illness, birth, death and other social events. One is through their dugda deebii (help turn by turn) institution. In this system addooyyee institution come together to help each other on farming turn by turn. They work meesii (cleaning ploughed farm land to prepare to distribute seed), aramaa (weeding), and others. They help each other according to their addooyyee institution. The other institution through which addooyyee institution help each other is daboo durbaa (girls' cooperative work). They help each other through daboo (cooperative work), when one of their addooyyee unable to finish her works on time because of different social issues such as birth, illness, death and other reasons.

After marriage, if one of their addooyyee gave birth, the institution helps her in the farming. They work on weeding, meesii, haamaa (mowing) and other harvesting works. They appoint the day on which they help her and participate in unity. Not only farming, they also wash her cloth and body and prepare shananii birth ritual. During the birth event addooyyee institution also affords each other gumaata dhalaa (gift of birth). Gumaata dhalaa is the food that addooyyee institution prepares at their respective home and present for their addooyyee who give birth. Even though they are far from each other, they present it carrying from their residence to there. They visit each other by gumaataa (food prepared for women who give birth from her relatives, neighbors and friends) of cultural foods such as marqaa (porridge), kukkutaa, cumboo (thick local bread), and coffee ceremony.

\section{Acknowledgement}

First, we would like to say thanks to Jimma University in general, Research Coordinating Office of College of Social Science, and Humanity in particular for sponsoring the research, which helped for the success of the work. Secondly, our thanks go to the cultural knowledgeable elders for their kindly assistance in giving information about the issue. Without their generous support, this work would have not been accomplished. Lastly, not the least, we like to thank Culture and Tourism Office for their generous help to give us necessary information.

\section{References}

Abass, Ademola (2010). Protecting human security in Africa. United States. Oxford University Press.

Alemayehu Debelo Jorgo (2012).Conquest and change in Boorana traditional polity: A Study of Dynamism and Resilience of Indigenous Political Institutions." In the journal of Oromo studies. Vol.19 No.1\&2.

Alemayew Haile et al (2006). History of the Oromo to the sixteenth century. Finfinne: OCTBOromo Culture and Tourism Bureau.

Altarelli, Vanda (2003). Enhancing the role of indigenous women in sustainable development. IFAD experience with indigenous women in Latin America and Asia. Third session of the permanent forum on indigenous issues.

Amadiume, Ifi (1997). Re-inventing Africa: matriarchy, religion and culture.USA: St Martin's press, Inc.

Anene, Emmanuel (2011). African best baby names. United States of America: Authorhouse. 
Baines, Beverley, Daphne Barak-Erez, Tsvi Kahana, (eds) (2012).Feminist constitutionalism: global perspectives.USA: Cambridge University Press.

Belletech Deressa (1993). "The Economic Viability of Oromia and ItsImpact on the Politics of the Horn” In Mohammed Hassen (ed).The Journal of Oromo Studies. Vol.1 No.1 pp. 28-35.

Blackhurst, Hector (1996). "Adopting an ambiguous position: Oromo relationships with strangers." In Being and becoming Oromo: historical and anthropological enquiries. P.T.W. Baxter, Jan Hultin, Alessandro Triulzi (edts): United States: Red Sea Press, Inc.

Daniel Deressa (2002). "Continuity and change in the status of women: The case of Arsi Oromo living Adjacent to Upper Wabe Valley (Dodola).” MA thesis at Addis Ababa University.

Davidson, Cathy N. (2010). The Future of Thinking: Learning Institutions in a Digital Age. USA: MIT Press.

James, Valentine Udoh (1995).Women and sustainable development in Africa. USA: Greenwood Publishing Group.

Jeylan W. Hussein (2004). “A cultural representation of women in the Oromo society.” In African study monographs, 25(3): Pp. 103-147.

Fonjong, Lotsmart N., ed, (2012). Issues in women's land rights in Cameroon. Bameda: Cameroon : Langaa Research \& Publishing CIG.

Gehman, J. Richard (1989).African traditional religion in biblical perspective. Kenya: East African educational publishers Ltd.

Gruchy edts ( 1995). Living faiths in South Africa.United Kingdom: C. Hurst \& Co. (publishers) Ltd.

Kuwee Kumsa (1997). "The siiqqee institution of Oromo women.” In Asafa Jalata (ed.) The journal of Oromo studies Vol. 4, No. 1\& 2, pp. 115-152.

Martin, Guy (2012). African political thought. USA. Palgrave Macmillan.

Mbiti, S John (1990).African religious and philosophy, second edition. Great Britain: Biddles Ltd, King's Lynn, Norfolk.

Mesthrie, Rajend (ed) (2002). Language in South Africa. United Kingdom. Cambridge University press.

Mohammed Hassan (1994). The Oromo of Ethiopia: A History, 1570-1860. London. Red sea press. Østebø, Marit Tolo (2009). "Wayyuu - women's respect and rights among the Arsi-Oromo." In: Proceedings of the 16th international conference of Ethiopian studies, ed. by Svein Ege, Harald Aspen, Birhanu Teferra and Shiferaw Bekele, Trondheim 2009. pp. 1049-1060.

Paulos Milkias (2011). Africa in focus: Ethiopia.USA ABC-CLIO LLC.

Samatar, Said S. (1992). In the shadow of conquest: Islam in colonial Northeast Africa.Trenton, New Jersey: The Red Sea Press. 
Solomon, A. James (2010). Deliverance from demonic covenants and curses. USA: Xulon press.

Tanya, K. Gerald (2010).The Church-as-family and ethnocentrism in Sub-Saharan Africa. USA: Transaction publishers.

Tesema Ta'a (2006). The political economy of an African society in transformation: The case of Macca Oromo (Ethiopia).Germany: Otto Harrassowitz Verlag.

Regassa Aboma (2006). Gender and agricultural production among Maqi Oromo. Addis Ababa: the department of Sociology and Social Anthropology.

Tsega Etefa (2012). Integration and peace in East Africa: A history of the Oromo nation. USA: Palgrave Macmillan.

Valsiner, Jaan (2000). Culture and human development. Great Britain: SAGE publications, Ltd.

Varjopuro, Riku (2003). Conflicts between protected species and fisheries: social science research and policy approaches. Copenhagen: Nordic Council of Ministers.

Yoshida, Kanji (2013). "Masks and secrecy among the Chewa." In Frances Harding (2002).The performance arts in Africa: a reader. USA: Routledge.

\section{Internet Sources}

http://www.apa.org/pi/lgbt/resources/guidelines.aspx (Assessed in January, 3, 2015). wcd.nic.in/gbhb/Link\%20hand\%20pdf/Hand\%20Book\%20Chap\%202.pdf (Assessed in November, 7, 2014)

http://gubirmans.com/Addooyyee.htm (Assessed in November, 26, 2015)

http://oromiatimes.blogspot.com/Addooyyee.htm (Assessed in November, 26, 2015).

\section{Copyrights}

Copyright for this article is retained by the author(s), with first publication rights granted to the journal.

This is an open-access article distributed under the terms and conditions of the Creative Commons Attribution license (http://creativecommons.org/licenses/by/4.0/). 